\title{
Marketing Management of Competitiveness in the Residential Real Estate Market
}

\author{
Tatyana Zh. Solosichenko \\ Ural State University of Economics \\ Ekaterinburg, Russia
}

\author{
Nadezhda A.Goncharova \\ Ural State University of Economics \\ Ekaterinburg, Russia \\ nadin1325x@yandex.ru
}

\begin{abstract}
The gist of this article boils down to the marketing management of the competitiveness of enterprises in the real estate market. Development of a brand platform is a stage in building a marketing strategy, which is the foundation for creating a brand. The effective marketing strategy of the company should include the stage of developing a brand platform and be at the forefront in importance, among other issues. And how the company promotes itself in the market, how it promotes itself in the minds of consumers, partners, suppliers, and the media will determine the successful achievement of its strategic goals. The scientific hypothesis is expressed in the following thesis: reducing the degree of influence of external factors in the life of an enterprise in the construction industry, is closely linked to the need to introduce a competitiveness management system; to date, the lack of an integrated approach to the marketing system in construction industries reduces the economic and social efficiency of projects. A mechanism for assessing competitiveness on the basis of a marketing approach with the use of current methods is traced. A situational analysis based on the degree of influence of the external environment, namely: macroenvironment factors, a comprehensive assessment of competitors' activities in the real estate market of the city of Yekaterinburg and identifying consumer preferences, loyalty, and also given the characteristics of the internal potential of the Atomstroycomplex corporation. The market opportunities of the Atomstroycompleks JSC enterprise have been revealed and marketing management tools have been proposed, including increasing the efficiency of internal management processes, covering new territorial markets, increasing consumer loyalty. Final positioning concept is formulated in the paper.
\end{abstract}

Keywords-management; competitiveness; real estate market; marketing; situational analysis; market opportunities; competition; external environment; marketing research; consumer classification; loyalty index; internal potential; marketing program.

\section{INTRODUCTION}

The urgency of the problem of increasing the competitiveness of enterprises at all levels is due to increased competition in the markets, globalization of the world economy and lower economic barriers. Competition not only stimulates the development of markets, but also contributes to improving the quality of life of the population, and therefore plays not only a huge economic, but also a social role. The imbalance of supply and demand in the real estate market, as well as the crisis of the economic system - all this makes the problems of competition in this market particularly topical. Therefore, in order to prosper business, it is very important to introduce a system of marketing management of the organization's competitiveness.

The main objective of this study is to assess the marketing management of the competitiveness of enterprises in the real estate market. The scientific hypothesis is expressed in the following thesis: reducing the degree of influence of external factors in the life of an enterprise in the construction industry, is closely linked to the need to introduce a competitiveness management system; to date, the lack of an integrated approach to the marketing system in the field of development reduces the economic and social efficiency of projects.

Many scientists paid close attention to the problems of marketing management of the competitiveness of enterprises in various industries [1-20]. They call the management of competitiveness a specific management function, implemented through the performance of general functions in order to maintain and enhance the competitiveness of the enterprise and its products, which are components of a single system. You can also consider that this definition summarizes the specifics of the functioning of the competitiveness management system of enterprises in various sectors of the economy and management of enterprise competitiveness should be understood as a process that is a management function that purposefully affects the current and future level of competitiveness compared to enterprises producing similar products.

\section{BODY OF PAPER}

Managing the competitiveness of an enterprise is reduced to the formation of competitive advantages in all areas of the enterprise, but not by individual blocks of influence, but by a comprehensive, targeted solution of the tasks of managing the competitiveness of the enterprise. Managing competitiveness is to create an integrated system that includes: management at the production stage, management at the pricing stage, management of advertising policy and pre- and after-sales service, a generalized product can be described by the vector 
of its consumer and marketing properties. The main factors of ensuring competitiveness management are: personnel and their qualifications; quality of labor, effective organizational and economic management, quality management systems of processes at the enterprise, advanced production technologies and equipment, quality maintenance (maintenance services, service), information collection and processing technology, use of an information and marketing system for market conditions forecasting, risk management, functionally cost analysis Managing the competitiveness of an enterprise is a process, and a competitiveness management system is the mechanism that ensures this process.

In the enterprise competitiveness management system, the object of management is the competitive advantages of an enterprise, which are key factors and competencies that provide an enterprise with a more favorable position in comparison with competitors, as well as the achievement of strategic and tactical goals with optimal consumption of all types of resources.

The management system of enterprise competitiveness, as well as the enterprise management system as a whole, can be defined as a complex system. The complexity of enterprise competitiveness management systems is constantly growing, which is associated with continuous internal development occurring in the organization, constant changes in the management of enterprise competitiveness, internal and external conditions of operation, and this entails a change in the links between the elements of the system and the system as a whole.

The main goal in managing the competitiveness of an enterprise is to form the competitiveness of a product (service, technology) at the output, and this goal will be achieved while purposefully ensuring the competitiveness of the enterprise, both at the input of the system and during transformations. In this regard, an important element of any system, including the enterprise competitiveness management system, is the formation of feedback. This element of the system has the most significant role, since from the effectiveness of building feedback, its proper assessment, interpretation and selection of corrective actions depends on the overall efficiency of the enterprise competitiveness management system.

As a feedback in the enterprise competitiveness management system, there should be an assessment of the competitiveness of the enterprise, which is aimed at the rapid identification of deviations in the system and their localization. Over the past 5 years there has been a significant decrease in demand in the residential real estate market of the city of Yekaterinburg, which was caused by the deterioration of the economic situation in the country. Even earlier, the real estate market was experiencing explosive development: outstripping demand allowed developers to build and sell lowquality products: without a well-developed infrastructure, with non-functional planning solutions. During this period, a record increase in the number of developers was recorded in Yekaterinburg, a trend towards expansion of urban space and development of new land plots on the urban periphery appeared. The annual volume of delivery of residential real estate exceeded one million square meters, while most of the housing was sold at the construction stage.

The financial crisis of 2014-2015 has changed the market structure. Solvent demand fell to 500 thousand square meters. meters per year, but due to the inertia of the construction process, the volume of housing commissioned is still about a million squares per year. This led to a sharp increase in competition in the market, the emergence of a large amount of unsold finished housing and the formation of a new marketing approach: saturation of constructed facilities with additional functions and options, development and urgent integration of concepts into existing housing projects under construction. In recent years, Yekaterinburg has recorded stable growth rates for housing commissioning. A decrease in this indicator occurred only in 2009 , when about $40 \%$ of construction projects were frozen, and in 2013, when the introduction of a significant number of new buildings was postponed to the beginning of 2014, 2015 was a record for both Yekaterinburg and all Sverdlovsk regions. More than 1.0 and more than 1.4 million $\mathrm{m}^{2}$ of housing were commissioned, respectively. The most important for the housing market is the introduction of multi-apartment facilities. Yekaterinburg occupies a leading position in the commissioning structure of residential apartment buildings in the Sverdlovsk region with a share of about $65-75 \%$ [21].

Sverdlovsk region is the largest industrial region of the country, producing about $40 \%$ of all products of the Russian Federation. The regional economy shows stable growth, surpassing the average in Russia. Sverdlovsk region is among the five regions of the Russian Federation with the largest population, most of which is concentrated in the city of Yekaterinburg and nearby industrial clusters. In recent years, there has been a positive trend in the economic activity of the region. Operations with real estate and construction respectively occupy the $3 \mathrm{rd}$ and 5 th place in the structure of the gross regional product of the Sverdlovsk region. The building complex of Yekaterinburg and the Sverdlovsk Region is characterized by a large capacity, the presence of strong participants, the presence of its own production base, as well as projects that are comparable in complexity to the capital ones. 906 thousand $\mathrm{m}^{2}$ of multi-unit housing was introduced in 2017. At the same time, $46.8 \%$ of this volume of input was provided by five leading companies: Atomstroycomplex, RGS-Academichesky, LSR-real estate Ural, BrusnikaYekaterinburg, Sinara Development [22].

The peculiarity of the market is the competitive neighborhood of strong local developers and federal players, including LSR and PIK. In each neighborhood, several apartment building projects from different developers are being implemented simultaneously. Atomstroykompleks is one of the largest and only company that builds apartment buildings in all districts of the city, while construction sites of other developers are limited. In addition, Atomstroykompleks on all projects complies with its own high quality standard, including fine finishing and furnishing of apartments, private landscaped courtyards, and the creation of public spaces. In addition to the location, each of the developers competes with the "ASC" in another 1-2 parameters: 
difficulties. To avoid the bankruptcy of our own production, it is necessary to continuously stimulate the demand for the final product - residential and commercial real estate projects. In the conditions of preserving the stability of building production technologies, the company's factories are capable of generating profits in the overall portfolio and ensuring the supply of the company's site with building materials in a timely and complete manner.

The influence of the five driving forces that determine the possible level of profit in the market and represents a separate level of product competitiveness was considered: the market power of buyers; vendor bargaining power; the threat of invasion of new members; the danger of the appearance of goods - substitutes; level of competition or intra-industry competition:

- it is recommended to adhere to the cost leadership strategy;

- the company should focus its main efforts on building a high level of product knowledge and on building awareness of the unique features of the product;

- to maintain competitiveness, it is necessary to constantly monitor the proposals of competitors and the emergence of new players;

- focus on eliminating all the shortcomings of the product, reducing the number of requests for complaints (table 1):

industry relative to competitors, you can use open ratings published in business publications. Information about the market share of the company should be requested in professional communities and organizations. For the Sverdlovsk region, this is the Ural Chamber of Real Estate, whose specialists collect and analyze information on the state of the residential and commercial real estate market in the region.

The assessment of the probability of changes in the macroenvironment factors was carried out by brainstorming by the company's specialists. Important economic factors are the increase in unemployment and the fall in economic activity of the population. Socio-cultural factors have less impact on the company than economic and political factors. Among the most important socio-cultural factors, one can single out the migration of the population to large industrial centers and the expansion of the boundaries of the metropolis. Among technological factors, the stability of basic technologies plays a significant role. The company's portfolio includes its own factories for the production of building materials and related products, as well as its own fleet of special equipment. Significant changes in production technologies may necessitate the modernization of production, which will lead to significant financial costs.

One of the distinguishing features of the company " Atomstroycompleks " is the presence of its own factories of building materials and a park of special equipment. This allows timely deliveries of necessary materials and special equipment to the construction site, independence from thirdparty suppliers; improved construction technology, adapted to its own production; increased pace of construction. But, at the same time, with a sharp decline in demand and construction volumes, plants are beginning to experience financial
TABLE I. CONCLUSIONS ON THE STRATEGY OF 5 COMPETITIVE FORCES ACCORDING TO M. PORTER (COMPILED BY THE AUTHORS)

\begin{tabular}{|c|c|c|c|}
\hline Parameter & Value & Description & Work directions \\
\hline $\begin{array}{l}\text { The threat } \\
\text { from the } \\
\text { substitute } \\
\text { goods }\end{array}$ & high & $\begin{array}{l}\text { For apartments in } \\
\text { new buildings, } \\
\text { apartments in the } \\
\text { secondary market } \\
\text { serve as an } \\
\text { alternative. Also } \\
\text { for apartments in } \\
\text { monolithic houses } \\
\text { cheaper apartments } \\
\text { can be apartments } \\
\text { in panel houses } \\
\text { (PIK). }\end{array}$ & \multirow{3}{*}{$\begin{array}{l}\text { 1. It is recommended to adhere } \\
\text { to a cost leadership strategy. } \\
2 \text {. The company should focus } \\
\text { its main efforts on building a } \\
\text { high level of product } \\
\text { knowledge and on building } \\
\text { awareness of the unique } \\
\text { features of the product. } \\
\text { 3. To maintain } \\
\text { competitiveness, it is necessary } \\
\text { to constantly monitor the } \\
\text { proposals of competitors and } \\
\text { the emergence of new players. } \\
\text { 4. Focus on eliminating all the } \\
\text { flaws in the product, reducing } \\
\text { the number of complaints on } \\
\text { complaints. }\end{array}$} \\
\hline $\begin{array}{l}\text { Threats of } \\
\text { intra- } \\
\text { industry } \\
\text { competiti } \\
\text { on }\end{array}$ & middle & $\begin{array}{l}\text { About } 30-40 \\
\text { developers work in } \\
\text { the market of } \\
\text { Ekaterinburg. At } \\
\text { the same time, } 50 \% \\
\text { of the total input } \\
\text { volume is provided } \\
\text { by } 5 \text { leading } \\
\text { companies. }\end{array}$ & \\
\hline $\begin{array}{l}\text { The threat } \\
\text { of new } \\
\text { players }\end{array}$ & middle & $\begin{array}{l}\text { The risk of new } \\
\text { players entering the } \\
\text { market is low due } \\
\text { to the high level of } \\
\text { initial investment. } \\
\text { But the market is } \\
\text { attractive for } \\
\text { federal companies, } \\
\text { if they enter the } \\
\text { market, the } \\
\text { company's market } \\
\text { share is likely to } \\
\text { lose. }\end{array}$ & \\
\hline
\end{tabular}




\begin{tabular}{|c|c|c|}
\hline $\begin{array}{l}\text { The threat } \\
\text { of losing } \\
\text { current } \\
\text { customers }\end{array}$ & middle & $\begin{array}{l}\text { The level of } \\
\text { recommendations } \\
\text { of the company is } \\
\text { high, the company } \\
\text { also leads in terms } \\
\text { of brand awareness. } \\
\text { Nevertheless, there } \\
\text { is a risk of losing } \\
\text { customers due to } \\
\text { dissatisfaction with } \\
\text { the quality of goods } \\
\text { and greater } \\
\text { confidence in } \\
\text { federal companies. }\end{array}$ \\
\hline $\begin{array}{l}\text { The threat } \\
\text { of } \\
\text { supplier } \\
\text { instability }\end{array}$ & middle & $\begin{array}{l}\text { In the company's } \\
\text { portfolio, there are } \\
\text { own factories for } \\
\text { the production of } \\
\text { building materials, } \\
\text { supplies are carried } \\
\text { out steadily. But } \\
\text { there is a high } \\
\text { dependence on the } \\
\text { cost and timing of } \\
\text { the connection of } \\
\text { networks, other } \\
\text { custom positions } \\
\text { and exchange rates } \\
\text { when purchasing } \\
\text { raw materials. }\end{array}$ \\
\hline
\end{tabular}

The assessment of the competitiveness of Atomstroycompleks JSC was carried out using the method of simple and weighted scoring of competitors. Comparison rates were selected based on the 2017 survey consultant of the Marketing Consultant group. The main parameters by which consumers determine the positioning of the developer are: construction in environmentally clean areas, a large selection of objects, high quality construction and materials, the reliability of the developer, beautiful design of houses, good planning and delivery of objects on time. The results of the scoring are shown in table 2:

TABLE II. SCORING COMPETITIVENESS (COMPILED BY THE AUTHORS)

\begin{tabular}{|c|c|c|c|c|c|c|c|c|c|c|}
\hline \multirow[b]{3}{*}{ № } & \multirow[b]{3}{*}{$\begin{array}{c}\text { Indicators of } \\
\text { the comparison } \\
\text { of construction } \\
\text { companies }\end{array}$} & \multirow[b]{3}{*}{ 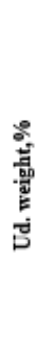 } & \multirow{2}{*}{\multicolumn{2}{|c|}{$\begin{array}{c}\text { JSC } \\
\text { Atomstroy } \\
\text { complex }\end{array}$}} & \multicolumn{6}{|c|}{ Competitors } \\
\hline & & & & & \multicolumn{2}{|c|}{$\begin{array}{l}\text { LSR Real } \\
\text { estate Ural }\end{array}$} & \multicolumn{2}{|c|}{ Brusnika } & \multicolumn{2}{|c|}{$\begin{array}{c}\text { RGS } \\
\text { Akademic } \\
\text { heskoye }\end{array}$} \\
\hline & & & 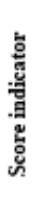 & 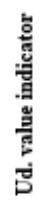 & 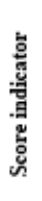 & 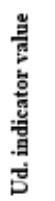 & 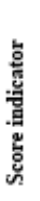 & 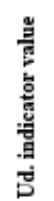 & 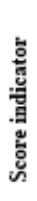 & 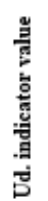 \\
\hline 1 & $\begin{array}{l}\text { Development } \\
\text { (conceptual } \\
\text { development, } \\
\text { built-up areas) }\end{array}$ & 14 & 8 & 1,12 & 7 & 0,98 & 9 & 1,26 & 7 & 0,98 \\
\hline 2 & $\begin{array}{l}\text { Planning and } \\
\text { Design } \\
\text { Solutions }\end{array}$ & 12 & 10 & 1,2 & 7 & 0,84 & 8 & 0,96 & 9 & 1,08 \\
\hline 3 & $\begin{array}{l}\text { Average offer } \\
\text { price }\end{array}$ & 10 & 8 & 0,8 & 9 & 0,9 & 8 & 0,8 & 9 & 0,9 \\
\hline 4 & $\begin{array}{l}\text { Large selection } \\
\text { of objects }\end{array}$ & 10 & 10 & 1 & 7 & 0,7 & 7 & 0,7 & 7 & 0,7 \\
\hline 5 & $\begin{array}{l}\text { The reliability } \\
\text { of the developer }\end{array}$ & 10 & 9 & 0,9 & 9 & 0,9 & 8 & 0,8 & 8 & 0,8 \\
\hline
\end{tabular}

\begin{tabular}{|c|l|c|c|c|c|c|c|c|c|c|}
\hline 6 & $\begin{array}{l}\text { Qualification of } \\
\text { sales managers }\end{array}$ & 8 & 6 & 0,48 & 7 & 0,56 & 9 & 0,72 & 8 & 0,64 \\
\hline 7 & $\begin{array}{l}\text { Product } \\
\text { promotion } \\
\text { (creative and } \\
\text { advertiging } \\
\text { campaigns) }\end{array}$ & 8 & 7 & 0,56 & 6 & 0,48 & 7 & 0,56 & 6 & 0,48 \\
\hline $\begin{array}{l}\text { Uninternupted } \\
\text { supply of } \\
\text { building } \\
\text { materials and } \\
\text { independence } \\
\text { from third-party } \\
\text { suppliers } \\
\text { through their } \\
\text { own production }\end{array}$ & 8 & 10 & 0,8 & 7 & 0,56 & 5 & 0,4 & 5 & 0,4 \\
\hline 9 & $\begin{array}{l}\text { The use of new } \\
\text { technologies in } \\
\text { construction }\end{array}$ & 8 & 9 & 0,72 & 8 & 0,64 & 8 & 0,64 & 7 & 0,56 \\
\hline 10 & $\begin{array}{l}\text { Informative site } \\
\text { of the company }\end{array}$ & 6 & 7 & 0,42 & 8 & 0,48 & 9 & 0,54 & 8 & 0,48 \\
\hline 11 & $\begin{array}{l}\text { The volume of } \\
\text { housing } \\
\text { construction in } \\
\text { 2017(sq. M.) }\end{array}$ & 6 & 10 & 0,6 & 5 & 0,3 & 8 & 0,48 & 5 & 0,3 \\
\hline & Total: & 100 & 94 & 8,6 & 80 & 7,34 & 86 & 7,86 & 79 & 7,32 \\
\hline
\end{tabular}

In general, the strengths of market participants are related to the affordability of the price per square meter and the qualifications of sales managers, in which the largest participant, Atomstroycomplex, lags far behind. The defects mainly come down to a limited choice of the construction object, planning decisions, and landscaping issues.

Marketing competitiveness management involves a thorough analysis of consumer preferences. The previous analysis showed that Atomstroycomplex is inferior to large competitors in the qualified work of sales managers. To evaluate the work of sales managers and customer satisfaction with the Atomstroykompleks product, we conducted marketing research. The main questions are related to the assessment of the quality of work of real estate agency managers and the assessment of the quality of real estate.

Using the method of multiple regression analysis, the influence of such factors as the manager's knowledge about the product, its politeness and activity on the overall opinion of the employee's work was evaluated. The constructed regression model showed that the activity and efficiency of his work have the greatest impact on the general opinion about the employee's work, as can be seen from the highest value of the standardized Beta regression coefficient equal to 0.626. The factors that influence the general opinion about the employee's work in order of their importance were also identified: activity and efficiency of work; politeness and pleasure of communication; knowledge of the expert about the object. Further, the influence of such factors as the general opinion on the work of the employee, the overall quality of the house, finishing, planning, improvement on the general opinion on working with Atomstroycompleks was evaluated. Based on the analysis of the values of the Beta coefficients, the main factors that influence the overall impression of purchasing an apartment in Atomstroycomplex in order of their importance are determined: the overall quality of the house; general opinion on the work of the employee; quality finish of the apartment; landscaping.

As a result of the analysis, 5 clusters were identified. The most numerous - the cluster number 2 numbering 295 people. 
- The market leader in the Sverdlovsk region and the city of Yekaterinburg. Over the past years, Atom JSC has been one of the top three or tops the list of leaders in terms of the number of square meters of housing commissioned. The company's market share in the number of square meters of housing commissioned is up to $15 \%$;

- one of the strengths of the company is a high proportion of recommendations and a high degree of brand awareness. According to the results of research conducted by the advertising group Deltaplan in 2016, 58\% of respondents would recommend purchasing an apartment in Atomstroycomplex JSC to their friends and acquaintances. The survey results show that the level of recommendations of Atomstroycomplex is very high compared with other developers. The share of recommenders is directly interconnected with brand awareness. With a high level of recommendations, they can be an effective channel of communication. According to the federal marketing research of developer awareness conducted in 2017 by the Marketing Consultant group, Atom is a leader in all levels of brand awareness: top-of-mind, spontaneous and induced awareness;

- own marketing and advertising department, a large number of specialists of the department. The qualification of the specialists of the department allows developing advertising campaigns and creative companies independently, carrying out the necessary research of the company's consumers and evaluating the effectiveness of the investment in advertising and marketing. Also in the structure of the company there is a department of strategic development, whose responsibilities include the development of concepts for development projects, competitive analysis, work to improve the environment of existing residential complexes - the creation of neighborhood centers and the management of communities of residents;

- good and flexible pricing policy. Pricing is carried out by way of market analogs. There is a monthly monitoring of prices and stocks of competitors, which are set at the price of the company's products. The company has developed several programs for acquiring real estate: installment plans for readymade and newly built housing, offsetting secondary housing, discounts for full payment, monthly pool of special offers, seasonal promotions;

- continuous work to improve the quality of housing. Atomstroycomplex was the first company in the real estate market to start building apartments with a fine finish, fully ready for relocation; close yards from entering cars. In 2016, a new quality standard was introduced - furnished apartments, designer bathroom furnishings, increased functionality of public spaces (wheelchairs, children's playrooms, designer furnished halls). From 2018, "free planning" apartments will be available for sale, in which residents can complete the planning to their own taste;

- sustainable GR (interaction with public authorities). Over the long years of its existence, the company has implemented many government orders: municipal kindergartens, schools and hospitals; such significant projects as the construction of the legislative assembly of the city of Yekaterinburg, the restoration of the Metenkov house, etc. are on the company's account;
In the marketing policy of the company were highlighted strengths:

\section{CONCLUSIONS}


- decline in sales due to the unstable economic situation in - convenient location of the sales office and services for registration of real estate transactions. The sales office is located in the center of the city, well equipped. Buyers are provided with a full range of services - from consulting on real estate to processing transactions and registering real estate. Also in the office you can arrange a mortgage, thus, in the office of a real estate agency provides a full range of services for registration of real estate transactions;

- loyalty program "ASC-Bonus". Thanks to the "ASCBonus" program, residents of the new buildings of Atomstroykompleks can purchase related products (furniture, plumbing, etc.) of partner firms at a discount, which increases customer loyalty;

marketing research. Before developing a project, a thorough study of consumer demand on the land plot under consideration is being conducted. As a result of the research, recommendations are given on flat-cartography, competitor analysis, and the rate of sales is predicted. If necessary, additional research company hires third-party consultants to analyze the current state of the real estate market in Yekaterinburg.

The marketing weaknesses of a company are:

- the complexity of communication between departments due to the large number of companies. The complexity of communications increases the timing of decision-making, a large number of employees participate in the decisions;

- lack of strategic sales planning and brand promotion;

- unsystematic consumer research (satisfaction, brand knowledge, consumer demand).

\section{Production weaknesses:}

- full production cycle. Due to the unstable economic situation and, as a result, a decrease in consumer demand, losses are incurred not only by the group of companies engaged in the direct construction of buildings, but also by their own factories and production sites, which are loaded to $50 \%$ with the supply of building materials and maintenance of Atomstroycomplex construction sites.

Identify threats to the external environment of the enterprise.

- growing competition in the market, the arrival of federal developers in the region. Loss of strength and loss of brand image, reduction in the share of recommendations as a result of the entry of strong federal developers into the market. Despite the excellent performance of research on the level of recommendations and brand awareness of the Atomstroycomplex company, with the entry of large federal players into the market, there is a danger of losing market positions. One of the determining factors can be identified unpredictable changes in consumer attitudes and the aggravation of global competition;

- raising the key rate on mortgage loans. An increase in mortgage rates may trigger a decline in demand for housing; the country and the fall in the average per capita cash income of the population and the increase in unemployment;

- the emergence of new materials and construction technologies, as a result - the obsolescence of building materials produced in our own factories (silicate brick);

- decrease in market capacity;

- changing consumer preferences.

Summing up, it is necessary to list the fundamental competitive advantages of the enterprise JSC Atomstroycompleks Corporation: brand; quality of facilities under construction; the volume of housing input; qualified personnel; customer loyalty; financial stability.

Managing competitiveness implies a set of measures for the continuous improvement of the product, the systematic search for new sales channels, new market segments, improvement of the quality of service and advertising. The relevance of marketing and interest in effective management of it are most enhanced by increasing the number of organizations creating similar products, aimed at meeting the same needs, that is, in a competitive environment, when marketing is a key part to profit. The real estate market in the city of Yekaterinburg will always exist in conditions of turbulent competition, and the main threat comes from new federal participants. It is also necessary to understand that the social significance of housing facilities is quite high, which ensures a high quality of life for citizens and is the highest possible level of reducing tension in society. The implementation of the program will allow the company to improve financial results, increase the share of sales in the real estate market, attract new customers. In order to retain potential consumers and increase the market share of the company, it is necessary first of all to improve the work with clients, increase the cost of advertising campaigns, expand the territorial coverage of consumers - going beyond the Ural region. All this will allow the JSC Atomstroycomplex Corporation to increase its turnover, profit and profitability, which will entail an increase in the share of the real estate market.

\section{References}

[1] Key, T.M., Czaplewski, A.J. (2017). Upstream social marketing strategy: An integrated marketing communcations approach, Business Horizons the Journal of the Kelley School of Business, vol. 60, pp. 325333.

[2] Kannan, P.K., Hongshuang (2017). Alice Li Digital marketing: A framework, review and research agenda, International Journal of Research in Marketing, vol. 34, pp. 22-45.

[3] Sammy, C. H. Li, Robinson P. (2017). Destination marketing: The use of technology since the millennium, Journal of Destination Marketing \& Management, vol. 6, pp. 95-102.

[4] A. Mack, E., Marie-Pierre, L. and Redican, K. (2017). Entrepreneurs use of internet and social media applications, Telecommunications Policy, vol. 41, pp. 120-139.

[5] Dong, T., Liang, C. Xu He (2017). Social media and internet public events, Telematics and Informatics, vol. 34, pp. 726-739.

[6] Pinho, C., Franco, M. and Mendes L. (2018). Web portals as tools to support information management in higher education institutions: A 
[16] Axel Grossmann, Lowell Mooney and Michael Dugan (2018). Inclusion fairness in accounting, finance, and management: An investigation of Astar publications on the ABDC journal list, Journal of Business Research, vol. 95, pp. 232-241.

[7] Erkut İ. İşeri, Kaan Uyar, Ümit İlhan (2017). The accessibility of Cyprus Islands Higher Education InstitutionWebsites, Procedia Computer Science, vol. 120, pp. 967-974.

[8] Urbano, D., Aparicio, S., Guerrero, M., Noguera, M. and TorrentSellens, J. (2017). Institutional determinants of student employer entrepreneurs at Catalan universities, Technological Forecasting and Social Change, vol. 123, pp. 271-282.

[9] Brennan, L., Vinh Nhat Lu and Tania von der Heidt (2018). Transforming marketing education: Historical, contemporary and future perspectives, Australasian Marketing Journal (AMJ), vol. 26, pp. 65-69.

[10] Raynard, M. (2017). Understanding Academic E-books Through the Diffusion of Innovations Theory as a Basis for Developing Effective Marketingand Educational Strategies, the Journal of Academic Librarianship, vol. 43, pp. 82-86.

[11] Gene R. Laczniak, Patrick E. Murphy (2018). The role of normative marketing ethics, Journal of Business Research.

[12] Abdel Monim Shaltoni (2016). E-marketing education in transition: An analysis of international courses and programs, The International Journal of Management Education, vol. 14, pp. 212-218.

[13] Fulvio Castellacci, Vegard Tveito (2018). Internet use and well-being: A survey and a theoretical framework, Research Policy, vol. 47, pp. 308325.

[14] Chun-Wei Chang, Jonathan Z. Zhang (2016). The Effects of Channel Experiences and Direct Marketing on Customer Retention in Multichannel Settings, Journal of Interactive Marketing, vol. 36, pp. 7790.

[15] Samantha N. N. Cross, Mary C. Gilly (2017). The impact of diversity on institutional longevity, International Journal of Research in Marketing, vol. 34 , pp. 231-251.

[17] Niccolò Pisani, Arno Kourula, Ans Kolk and Renske Meijer (2017). How global is international CSR research? Insights and recommendations from a systematic review, Journal of World Business, vol. 52, pp. 591-614

[18] The concept of export of educational services of the Russian Federation for the period of 2011-2020. [Online]. Available: http://vi.russia.edu.ru, free.

[19] Goncharova N. A., Kondratenko I. S., Zamaraeva E. N. Economic mechanism of industrial enterprise resources management efficiency assessment. The Journal of Social Sciences Research. 2018. T. 4. № 12.C. $470-477$.

[20] Solosichenko T. Zh., Nesterova Z. V., Goncharova N. A. Modern aspects of internet marketing development in educational institutions in the context of globalization. 18th International Scientific Conference Globalization and its Socio-Economic Consequences. University of Zilina, Faculty of Operation and Economics of Transport and Communications, Department of Economics. 10th - 11th October 2018. C. $2352-2361$.

[21] Rating of language centers of Ekaterinburg 2015 [Electronic resource]. Access mode: http://ekb.dk.ru/wiki/reyting-yazykovyh-tsentrovekaterinburga-2015 (appeal date: 04/05/2018).

[22] Hitesh Bhasin. Service Marketing Mix - 7P's of marketing [Electronic resource]. - Access mode: http://www.marketing91.com/servicemarketing-mix (access date: 03/15/2018).

[23] Powerbranding [Electronic resource]. - Access mode: http://powerbranding.ru/ (appeal date: 03/21/2018). 